John Carroll University

Carroll Collected

2017

\title{
Reimagining Nicaragua's Volcanto Tradition through the Music of Perrozompopo
}

Megan Thornton

John Carroll University, mthornton@jcu.edu

Follow this and additional works at: https://collected.jcu.edu/fac_bib_2017

Part of the Latin American Languages and Societies Commons

\section{Recommended Citation}

Thornton, Megan, "Reimagining Nicaragua's Volcanto Tradition through the Music of Perrozompopo" (2017). 2017 Faculty Bibliography. 34 .

https://collected.jcu.edu/fac_bib_2017/34 


\section{Reimagining Nicaragua's Volcanto Tradition through the Music of Perrozompopo}

\author{
Megan Thornton \\ John Carroll University
}

sociopolitical movements for centuries; however, it developed as a pan-Latin American movement along with political unrest in the 1960s. While the terms "protest music," "testimonial music," "new song," and "trova music" are used interchangeably throughout Latin America to describe socially committed music, a label specific to Central America is volcanto, a combination of volcan and canto, inspired by the line of volcanoes running along the region's western side (Scruggs, "Socially" 43-44). The term was coined after the 1979 left-wing triumph of the Frente Sandinista de Liberación Nacional (FSLN, or Sandinistas) in Nicaragua. Although the term was meant to encompass Central American testimonial music, it became a specific reference for popular music in Nicaragua during the 1980s (44). Carlos Mejía Godoy is known as the most influential composer of socially committed music in Nicaragua and the singer-songwriter most associated with the Sandinistas. His musical style and also the volcanto tradition continue to influence younger generations of musicians in Nicaragua, including his nephew Ramón Mejía. ${ }^{1}$

Ramón Mejía, better known as Perrozompopo, has social and musical advantages because his name will always be associated with the volcanto tradition; however, his focus on urban spaces and contemporary social problems somewhat distances his songs from the more traditional protest music steeped in rural folklore. As a singer-songwriter who writes his own socially committed lyrics, he is grounded in the volcanto tradition, yet his style is an alternative urban rock that mixes such music genres as rock, pop, hiphop, and blues. This modern twist to Mejía's musical style is reminiscent of global sensation Manu Chao or Argentina's Los Aterciopelados or Mexico's Café Tacuba, thereby encouraging listeners to rethink and reimagine the volcanto tradition. By mixing volcanto lyrics and autochtonous characteristics with rock and pop fusions, Mejía's music offers a perfect example of how contemporary musicians are creating hybrid, transnational styles. Thus, in this article, I argue that Mejía infuses Nicaraguan volcanto music with global sounds, creating a hybrid musical style with utopian longings for a more just society.

Mejía's stage name, Perrozompopo, is a perfect example of how he draws on popular imagination to bring the past and present together in his music, hence solidifying his artistic persona. The name connotes a transparent lizard found primarily in city homes and considered a national symbol, and it is also the title of a song on his first album. In an interview with BBC Mundo's Néfer Muñoz, Mejía explains his adopted name:

Quería tener un nombre distinto, que englobara una personalidad, una forma de escribir canciones y una actitud para escribir esas canciones. . . Las lagartijas o perrozompopos son un animal común en las paredes y los rincones urbanos. En el pasado, en Nicaragua los perrozompopos fueron usados como protectores de plagas para prevenir 
la fiebre amarilla. Ahora mi tarea es combatir la plaga de la indiferencia. (Muñoz)

The name Perrozompopo, therefore, is used throughout this essay because it emphasizes Mejía's intention of enacting social change through his craft, a commitment that will continue to unfold as my analysis reveals his artistic endeavors and musical influences.

Perrozompopo's music crosses national borders and musical genres to voice concerns about social injustices and to offer a space of resistance. His first album Romper el silencio (2004) combines musical influences ranging from rap and blues to flamenco and rock with the guitar as his signature sound. Although he recorded the album in Spain, he wrote the songs in Managua with Nicaraguan listeners in mind. The album title's social implications of breaking the silence about political corruption and foreign dominance in Nicaragua give way to protest songs like "Quiere a tu país," "Nos quieren dejar sin pinol," and the title track "Romper el silencio." This title track became the theme song for encouraging young adults to vote in Nicaragua's 2006 elections in which Carlos Mejía Godoy was a vice-presidential candidate. Perrozompopo's second album Quiero que sepas (2007) is a transnational collaboration with Costa Rican musicians that was produced by the Central American label Papaya Music and also showcases songs with socially committed lyrics by addressing the topics of migration, violence, and the marginalization of women. Furthermore, his third album Canciones populares contestatarias (2010) was recorded in Nicaragua with the help of the Centro Cultural de España and Momotombo Producciones and was available to download for free on his website in an attempt to reach listeners from different social, economic, and national backgrounds. This third album, known by the abbreviated title CPC, launched Perrozompopo onto the international stage with a Latin Grammy Nomination for Best Alternative Album in 2010. His most recent album Mundo (2014) piggybacks this nomination with less politically charged songs that touch on more universal themes in an attempt to reach a wider audience. It was produced by Cosmica Records in Los Angeles and is his first album to appear on iTunes, which showcased Perrozompopo as a Latin American Artist of the Week in 2014 (Roiz). As is discussed, Perrozompopo's albums reveal an arc to his career that starts with national and regional issues and then broadens to the global stage with a clear marketing strategy to attract a diverse listening public without taking away from his commitment to social justice.

Because Perrozompopo combines global pop and rock sounds with lyrics that contribute to the local tradition of socially committed protest music, his songs are "glocal" compilations that help tease out the tensions among local, regional, and international influences that have plagued Nicaragua for centuries. ${ }^{2}$ Perrozompopo's syncretic songs can also be classified as "audiotopias," a concept defined by Josh Kun as "sonic spaces of effective utopian longings" (23). Drawing on Foucault's idea of heterotopias, or unreal spaces of possible utopias, Kun argues that music brings into contact incompatible sites, offering listeners and musicians "new maps for re-imagining the present social world" (22-23). Following this line of thinking, Perrozompopo combines the global and local, often seen as incompatible in Latin America, through his craft and at the same time reimagines possibilities for Nicaragua and its place in the world. As Kun writes, music provides access to other worlds, creating a tool for social change and for community building (4). He insists that the feelings inspired by music can lead to utopian dreams of who we want to be and how we want the world to be (17). In this vein, protest songs are a perfect example of musical longings for a more just world. Perrozompopo's songs about the pitfalls of neoliberalism, violence against women, or the difficulties of migration, for example, are powerful audiotopias that project, from his viewpoint, a united dream in which race, class, gender, and nationality do not matter.

Before looking more specifically at Perrozompopo's audiotopias, it is important to understand his roots in Nicaragua's volcanto tradition and the Latin American Nueva Canción, or New Song, in general. Nueva Canción is a catchall term for socially committed music throughout Latin America, but it has strong ties to the Southern Cone. Chile's Violeta Parra (1917-1967) and Argentina's Atahualpa Yupanqui (1908-1992) were important precursors to the musical movement that solidified in the 1960s with struggles for social equality and political freedom (Arriaza). ${ }^{3}$ Argentina's Mercedes Sosa (1935-2009) and Chile's Víctor Jara (1932-1973), who was killed during Augusto Pinochet's military coup, as well as Cuba's Silvio Rodríguez (1946-), are today emblematic of Latin American Nueva Canción. ${ }^{4}$ Their music, and testimonial music in general, was not a commercial venture but rather an attempt to communicate social and political messages to the people. In "Un vistazo a la trova y su historia" Alejandro Arriaza describes the ideological function of Nueva Canción. He writes, "Temas difíciles, nada para distraer o pasar el rato, todo para cuestionar, para enfrentar, para obligar a la reflexión" ("Un vistazo"). Arriaza also situates Latin America's socially committed music in the oral tradition of the juglares or trovadores from medieval Spain, whose job was to orally inform and describe current events before print capitalism and the advent of newspapers ("Un vistazo"). Thus, the desire to inform and give testimony bridges Latin America's Spanish roots and the Nueva Canción movement.

The music and lyrics of Nueva Canción greatly influenced Central American musicians; however, local histories and heroes were also instrumental in shaping testimonial music in Nicaragua. Before the term volcanto came into play in the 1980 s, a tradition of political music already existed. As early as the 1850s, music helped to defeat William Walker, the North American filibusterer who tried to establish an English-speaking colony in Nicaragua (Scruggs, "Socially" 44). Later in the 1920s and 1930s, the corrido, 
or "musical newspaper" of the Mexican Revolution, was adopted to foster resistance against foreign dominance $(44-45)$. The corrido is a song form comprised of four-line verses that often narrates the heroic adventures of a leader and concludes with a moral message. In the case of Nicaragua in the early twentieth century, the corridos focused on the feats of Augusto César Sandino, who developed a mass movement to defend national sovereignty and to fight an invasion by the US Marines (44). Sandino became a symbol of resistance and a national hero. He was assassinated in 1934 by the proUS National Guard Forces of General Anastasio Somoza, who took control of the country two years later in a military coup. The country was then controlled by the Somoza family for more than forty years (1936-1979), during which time foreign cultural models, especially from Mexico and the United States, were valued over autochtonous ones (Scruggs, "Central" 173-74). Repression and impoverishment of the general population under the Somoza dynasty and the 1972 earthquake that devastated the capital city of Managua created opportunities for revolutionaries to foment an uprising. Thus, drawing on the legacy of Sandino, the FSLN appropriated both his name and his use of music to connect to el pueblo and to successfully mobilize people against the Somoza dictatorship. A primary goal of the Sandinistas was to valorize the popular classes and their cultural manifestations, which had been devalued and degraded under the Somoza dynasty.

Carlos Mejía Godoy was sympathetic to the Sandinista cause and thus became one of their biggest political champions and cultural liaisons. In "Socially Conscious Music Forming the Social Conscience," the ethnomusicologist T. M. Scruggs writes that the music of Carlos Mejia Godoy was "on par with all other organizing efforts in generating the success of the anti-Somoza struggle" ("Socially" 49). His political ties and musical career therefore helped shape the volcanto movement. Scruggs explains that Carlos Mejía Godoy combined Nueva Canción lyrics with three popular elements, Mexican norteño styles, son nica characteristics, and colloquial language, to become the most influential composer of socially committed music in Nicaragua (48-55). To appeal to the masses and to help create an imagined community, he adopted the four-octave piano-keyboard accordion from Mexican norteño music, which was popular in his native region of northern Nicaragua, and drew on the son nica tradition, a uniquely Nicaraguan sound from the southern region's marimba de arco tradition. ${ }^{5}$ His use of popular expressions and vernacular language further rooted his songs in lo nacional. He created such signature songs as "María de los Guardias" and "Cristo ya nació en Palacaguiina" to criticize the Somoza regime and to communicate with el pueblo throughout the tumultuous 1970s. In 1978 he teamed up with his brother Luis Enrique to write the music and lyrics for Guitarra armada, an album with explicit instructions for the general population to take up arms against Somoza. After the 1979 triumph of the Sandinistas, Carlos Mejía Godoy's musical message for social change endured and continues to influence his contemporary counterparts. As with Perrozompopo, music is still an important (trans)national cultural form that delivers information and communicates ideologically charged, and perhaps utopian, messages to el pueblo.

While Perrozompopo grew up listening to his uncle's music and to volcanto music in general, his music career took shape during the 1990s when local cultural production all but ceased to exist in Nicaragua. Statesupported, pro-Sandinista volcanto music flourished during the 1980s until funding was cut because of economic hardships from the US-imposed embargo and the US-led Contra war (Scruggs, "Music" 259). Moreover, when a pro-US government was elected in 1990, state-sponsored cultural projects were completely eliminated in an attempt to erase the Sandinistas' cultural legacy (260-62). North American and Latin American mainstream music overshadowed local productions to the extent that bootleg recordings became the main product of the national music industry (264). The musicians, therefore, whose careers survived the revolutionary period, were forced to reinvent themselves, and many did so by incorporating the sounds of international pop and rock music into their repertoire. ${ }^{6}$ Rock music, in particular, became a vehicle for criticizing foreign dominance, neoliberal politics, and outside cultural models, thereby allowing for syncretic, hybrid combinations of global and local styles (267-69). Thus, while both music and lyrics were essential for traditional volcanto music, post-1990s volcanto music is defined by the meaning of its lyrics (Scruggs, "Music" 268; Sturman 25960 ). It became clear that one can enlist a variety of musical styles to engage the listening public with lyrics that make social and political critiques; hence, the music becomes the messenger. It is also important to note that since the turn of the millennium, volcanto music has received more attention with increased airtime on the radio, a budding tourist industry, and the revival of evening peñas, or live musical and cultural performances (Scruggs, "Music" $270-71) .{ }^{7}$ All of these changes have created a musical space for the creative audiotopias of Perrozompopo.

The title track on Perrozompopo's first album, Romper el silencio (2004), is a perfect example of an audiotopia, for it encourages listeners to break the silence about political corruption and social injustices. The lyrics are backed by a guitar-led rock melody with an alternative flare that builds at the end of the song to emphasize the chorus and main message: "hay que romper el silencio, del silencio tuyo." Its critique of power structures is an urgent call to action:

A pesar de la codicia del gobierno y su fragancia,

a pesar que en nuestra iglesia se negocie con dinero,

a pesar de tener miedo porque sabes de un verdugo,

que te costura los labios si lo dices por la radio,

hay que romper el silencio, del silencio tuyo. 
The lyrics also take listeners into a more personal domain by recognizing abuses over sexual preference: "que puedo ser detenido por querer al mismo sexo / por amar frente a este mundo, mundo de la indiferencia." While attacks on government and religious authorities and also a fear of censorship and sexual discrimination could place this song anywhere, the manifesto included at the beginning of the CD booklet specifically addresses listeners in Nicaragua. In this manifesto, Perrozompopo makes explicit and personal the need to speak out about foreign dominance, discrimination, corruption, and greed in Nicaragua, and then closes with an audio(u)topian dream: "tenemos el poder para cambiar las cosas, para lograr otra Nicaragua, otro mundo y que en la realidad sea posible" ("Manifiesto"). With this, Perrozompopo places the power with the individual and invites listeners to be the tool for social change.

It is important to note that Perrozompopo's uncle Luis Enrique also wrote a thought-provoking song titled "Romper el silencio" that appeared on his 1997 album Trovador errante. While Luis Enrique never achieved as much popularity as his brother Carlos Mejía Godoy, he is still very much associated with the volcanto tradition and continues to enjoy a successful music career in Nicaragua. His version of "Romper el silencio" is not political in nature but rather a ballad about domestic violence that tells the story of a woman, abused by her alcoholic husband, who dreams of escaping but ultimately stays with him. Perhaps it is pure coincidence that Perrozompopo uses the same title for his song, but it is suggestive to think of Nicaragua as the woman in this story who is abused by those in power (politicians, priests, police, and US presidents). Nicaragua seems to be caught in a similar cycle of violence as the woman in Luis Enrique's song.

The release in 2004 of Perrozompopo's "Romper el silencio" further supports my comparison, for it emerged during an important transition time in Nicaragua. After a series of corrupt, pro-US governments during the 1990s, voters reelected in the 2006 elections FSLN candidate Daniel Ortega, who had previously served as the leader of Nicaragua during the Sandinista revolutionary years (1979-1990). ${ }^{8}$ The song title, therefore, draws on popular imagination to recall the volcanto tradition and its message of sociopolitical change that helped oust the Somoza dynasty in 1979. Furthermore, Perrozompopo's song became the signature sound for Nicaragua's version of Rock the Vote, a movement that encouraged young people to participate in the political process and to have their voices heard (Lopez). However, it should be noted that the song was not partial to a particular office seeker, neither to the FSLN's Daniel Ortega nor to the MRS vice-presidential candidate Carlos Mejía Godoy. ${ }^{9}$ In an interview with Tim Rogers from Nicaragua Dispatch, Perrozompopo admits that times and politics have changed, meaning his family no longer aligns with the FSLN, but he reaffirms his family's support of social justice: "Being a revolutionary to me doesn't mean being a leftist; it's about generating change" (Rogers). The 2006 election results suggest that voters did break their silence to enact change, as Perrozompopo's song suggested, but it would appear that now Ortega has become the abuser. After winning the elections in 2006 and again in 2011 , despite allegations of voter fraud, Ortega shows no signs of stepping down from power. A 2014 change to the constitution eliminated term limits for the presidency, allowing him to run for and win a third consecutive term in 2016.

In addition to Perrozompopo's reuse of the song title "Romper el silencio," his first album acknowledges his family's musical legacy and the volcanto tradition in other ways. For example, he includes a remake of the song "La Tula cuecho," originally written and recorded by his uncle Carlos Mejía Godoy. While the original song is a more traditional folk song featuring the accordion, Perrozompopo recorded it as a contemporary song with rap and rock influences. Perhaps even more suggestive of the volcanto tradition is the list of vocabulary words included at the end of the CD booklet. Words like brete (trabajo), jaños (novios), and coco (cabeza) are popular Nicaraguan expressions that interpellate Perrozompopo's listening public, providing them with another interpretive tool for his songs. Scruggs uses the term escaliche to describe these localized references, which borrow from both English and indigenous languages, to produce a popular street-speech style that Nicaraguans claim to be "the most non-standard national Spanish spoken on the continent" ("Socially" 51). Carlos Mejía Godoy is famous for incorporating escaliche into his songs as a way to connect to elpueblo, and thus Perrozompopo's strategy is a nod to his uncle and the volcanto tradition.

Using these popular expressions in protest songs about neoliberalism and Nicaragua's place in the global economic system help personalize and problematize these issues for listeners. For example, the song "Nos quieren dejar sin pinol" draws on the popular understanding of pinol, a corn powder used to make drinks described as "el símbolo del alma nicaragüense." The title and lyrics suggest that the local economy and the individual worker are sacrificed in favor of big business and bottom lines, thereby robbing Nicaraguans of their identity (pinol). Furthermore, in "Quiere a tu país," Perrozompopo mixes rap, blues, and rock to produce a sonic space of utopian desire that reminds Nicaraguans to love their country and advises politicians to be "decentes." The singing voice identifies with the working class, recognizing those who get caught in the middle of a global economy: "La economía politizada / va a la derecha como a la izquierda, / y por el centro va tanta gente que nunca, nunca, les queda nada." It also situates itself in an urban setting by referencing "el tráfico que te mata" and the "maquiladoras," which in Nicaragua, as the CD booklet explains, refers to the women who work in transnational textile factories. These audiotopias are thus clear examples of how Perrozompopo combines the local and the global through music, lyrics, and popular expressions to connect to listeners who negotiate on a daily basis the juxtapositions of living in the twenty-first century. 
By recalling the volcanto tradition and his family's musical legacy, Perrozompopo's first CD establishes his artistic identity as an urban singersongwriter with social concerns and also his musical style as a hybrid mix ranging from rock and pop to rap and blues. His second CD takes this hybridization one step further by crossing cultural and musical borders to challenge listeners with new sounds and cultural connections. As previously mentioned, his second album Quiero que sepas (2007) was produced by the Central American label Papaya Music, a label housed in San José that was started in 2003 to showcase Central American musicians and the region's musical identity. ${ }^{10}$ This cross-cultural collaboration provided new musical opportunities that allowed Perrozompopo to work with both Costa $\mathrm{Ri}$ can and Nicaraguan musicians, to showcase such instruments as the piano and violin, and to weave in different background vocals. While Romper el silencio, the first album, has a more acoustic sound that highlights the guitar, this second album offers a more edited and refined sound. The connecting thread between the two albums, however, is Perrozompopo's socially committed volcanto lyrics that denounce social inequalities. A critique of neoliberalism and politics as elaborated on Romper el silencio is also present on the second CD in such songs as "Me hubiera gustado" and "Tráfico," but the primary focus of the second album is the marginalization of women and global migrations. These thought-provoking topics also call for some lightheartedness, and Perrozompopo responds with love. He concludes Quiero que sepas with the love ballad "Cuando tardas y demoras," which describes el amor as "un punto de partida en nuestra vida" and the "pilar que [nos] sostiene." This song is significant because of its audiotopian lyrics and because Perrozompopo recorded it on his first album, thereby providing another link between the two CDs and perhaps proposing that love is the answer to social injustices.

Issues related to the marginalization of women and global migrations highlighted on Perrozompopo's second album raise questions about social justice and intersect one another, as women may be forced to migrate to provide for their families. While women weave in and out of Quiero que sepas, they are the primary focus of three songs: "Mujeres del centro y del río," "Hasta el fin de la alegría," and "Las hijas del sol." On the CD liner notes, Perrozompopo dedicates the album to his mother, daughter, and "aquellas mujeres que han faltado a ellas mismas y han sido cómplices de tantos hombres, por política o por religión para seguir marginando a la mujer" ("Liner"). With this dedication, Perrozompopo opens up a sonic space of utopian desire in which all women are treated with respect and dignity and seen as equals. In the song "Mujeres del centro y del río," he deconstructs an understanding of traditional gender roles and acknowledges the various positions women occupy in today's society:

Trabajadoras, garotas pequeñas,

chinitas, morenas de pelo cortito, mujeres de fuerza a punta de flor y canela, mujeres Marías, mujer del mercado mujer que se vive la vida dos veces, mujeres con sueños de eterno silencio, mujer que me dio con su vientre.

Repetition of the word mujer(es) in this verse and throughout the song echoes in listeners' ears, emphasizing the diversity and multiplicity of women as workers, mothers, disadvantaged citizens, and dreamers. Female background vocals also echo throughout the song with a haunting presence, perhaps a mirror of the often marginalized position of women in the world.

Perhaps even more impactful is Perrozompopo's focus on gender violence in the songs "Hasta el fin de la alegría" and "Las hijas del sol." Both of these protest songs personalize the issue of violence against women through volcantolyrics and linguistic tactics that urge listeners to take action. "Hasta el fin de la alegría," for example, paints a graphic image of sexual abuse:

Cada vez se hace más crudo ser mujer en mi país, ser la dueña de mi cuerpo de mi falda y de mi voz, cada vez que de tu puño sale sexo con dolor, se me abren las heridas que dejas en mi vientre y me quedo retenida en este miedo de morir.

The use of the second-person narration in this verse and throughout the song directly addresses the listener and incriminates him or her as the abuser. This accusation thus implicates the listener as part of a systemic problem, urging him or her to fight for gender equality to ensure the safety of all individuals. The first-person perspective also makes the song feel more intimate and places the listener in direct contact with the abused. Furthermore, the ambiguous reference to "mi país" places this song anywhere, as it could refer to Nicaragua, Costa Rica, Spain, or the United States, which emphasizes that sexual abuse happens everywhere.

By focusing on the femicides in Ciudad Juárez, Mexico, "Las hijas del sol" takes listeners to a specific place but still treats the general issue of gender violence. The song title and lyrics refer to the hundreds of women who have been disappeared or brutally killed since 1993 in the desert of Ciudad Juárez. While theories about the perpetrator(s) range from gang violence and drug wars to serial killers and sadistic rituals, the femicides in Juárez have received international attention because of the Mexican government's perceived inaction and inability to solve the crimes. The first verse therefore reveals an attempt to inform listeners about the issue with the repeated phrase "sabían que":

Sabían que hay hombres que ponen la mira, y atrapan de un trago la luz de otro ser, 
sabían que hay hombres que rasgan las ropas del pecho que un día les dio de beber, ay de beber, sabían ustedes que existe un desierto de puras mujeres de rabia y dolor,

sabían que hay cientos de cuerpos dormidos de puras mujeres de Juárez las hijas del sol. . . .

As seen in "Hasta el fin de la alegría," Perrozompopo uses a similar linguistic tactic to address listeners, but this time his use of ustedes directs the message toward a collective group. Because the issue of violence against women goes beyond the individual and requires collective action, perhaps the use of ustedes is an attempt to create an international group consciousness in solidarity with Mexico and the women of Juárez, and with those touched by violent crimes in general. Thus, all three songs-"Mujeres del centro y del río," "Hasta el fin de la alegría," and "Las hijas del sol"-interpellate the listener with a clear desire to inform, making an audio(u)topian plea for gender equality and the protection of all individuals.

Singing in solidarity seems to bridge the topics of gender violence and global migrations on Perrozompopo's second album. With the title track "Quiero que sepas" and the song "Ríos de gente," he personalizes the issue of migration and represents it as a global and local phenomenon. "Ríos de gente," in particular, is one of Perrozompopo's most popular and influential songs to date, having affected audiences in Nicaragua and abroad. It gained popularity as the theme song for Pueblo de paso, a radionovela produced by the Costa Rican nongovernmental organization Voces Nuestras to educate listeners about undocumented migration in Latin America and its many facets, including economic, political, cultural, and human rights issues. ${ }^{11}$ The first season began in 2006 with ten episodes that played on 184 radio stations in Latin America and ten Spanish-speaking radio stations in the United States (Pérez). Pueblo de Paso was so popular that a second season aired in 2009 (Perez). The need to appeal to a radionovela's diverse listening public helps explain the universal nature of the lyrics to "Ríos de gente." The title, for example, could refer to the San Juan River between Nicaragua and Costa Rica or the Río Grande between Mexico and the United States or other rivers that function as national gateways. The music also emphasizes the theme of moving via rivers with a gentle piano and guitar duet that imitates the sound of running water at the beginning of the song. However, the softness fades away as the music crescendos to a more dissonant sound, forcing listeners to take notice of the chorus:

Dispuestos van ríos de gente hacia el norte,

buscando los pueblos donde dormirán

buscando la paz infinita del cielo,

buscando encontrarse una vida mejor.
Accordingly, the song recognizes that undocumented migration is a global phenomenon that draws in people from the Global South looking for a brighter future, and the voice of the song identifies himself somewhat ambiguously as "un inmigrante del mundo mundial, indocumentado un ser especial." The lyrics also acknowledge the different faces of migration, such as "la madre que dejó los hijos" and "gente distinta de todo color." Depicting an inclusive image of today's migrant invites listeners from all backgrounds to relate to this audiotopia.

It is important to note that the music video for "Ríos de gente" earned Perrozompopo the award for Best Video at Costa Rica's 2008 Muestra de Cine y Vídeo, because of its affective impact and representation of a pertinent social issue. The video, also a collaborative project between Nicaragua and Costa Rica, was directed by Marvin Murillo and is available for viewing on YouTube (http://www.youtube.com/watch?v=C7 00Sa9Mcw). By featuring "real" families holding pictures of absent mothers, fathers, sons, and daughters, the video personalizes the issue of migration. The use of photographs focuses viewers' attention on the absent family members, thereby emphasizing the sacrifices of those who have left behind their children, parents, and families to find work in other places. The pictures also create a meta-image for viewers, all while engaging their sense of hearing, which alludes to the multiple layers of migration-personal, familial, generational, political, and socioeconomic. The video's multisensory experience, there fore, creates a displaced synesthesia by stimulating the visual and the aural at the same time and perhaps the oral, if one sings along. It also deeply engages the public with a visual audiotopia, or what I call an audiovisutopia, that asks viewers to contemplate the human facets of an issue often overshadowed by political debates and neoliberal economics.

It is not by accident that Perrozompopo collaborated with Costa Rican producers and musicians on "Ríos de gente," its music video, and his entire second album. The collaborations were both purposeful and personal. ${ }^{12}$ Because Costa Rica is a popular destination spot for Nicaraguan migrants, the issue is a source of tension between the two countries. Furthermore, Perrozompopo has direct knowledge of this north-south migrant route, for he moved to Costa Rica with his family to escape the Somoza dictatorship and then returned to Nicaragua after the 1979 Sandinista victory (Muñoz). ${ }^{13}$ Even though he was a young boy at the time, he witnessed the discrimination that many Nicaraguans face in Costa Rica, an experience that he has channeled into his music (Muñoz). For example, the very name of Quiero que sepas and its title-track song expresses a desire to inform listeners about the difficulties that migrants encounter on their journeys. As a lighter rock ballad with piano accompaniment that highlights Perrozompopo's voice, this protest song serves as a wakeup call, advising listeners to take notice of the perilous north-south path that takes many Nicaraguans to neighboring Costa Rica: "Quiero contarte la dura historia de lo que pasa cuando 
vas de norte a sur." Such difficulties may include deceitful smugglers, loneliness, and even death. The music then crescendos to emphasize the repeated line of the chorus: "Cruza fronteras de norte a sur."

Given the two neighbors' geographical proximity, shared language, and cultural similarities, it is not surprising that the migrant route between the two countries has been well traveled. Nicaraguans represent both the largest immigrant group and the highest number of undocumented migrants in the country (Fouratt 145). Rising unemployment rates and poverty levels in Nicaragua have led to increased economic migrations since the early 1990s, in contrast to the political migrations during the Sandinista years (19791990). This most recent migratory wave tends to attract working-class, undocumented individuals and is characterized by its urbanization, feminization, and permanency (Alvarenga; Castro Valverde 32-37, 48). These changes have led to increased political tensions, human rights violations, and xenophobic prejudices. ${ }^{14}$ In Threatening Others, the Costa Rican sociologist Carlos Sandoval García addresses the perceived differences between the two countries that have led to xenophobia. He explains that the Nicaraguan "other" is associated with dark skin, poverty, less prestigious Spanish, and political turmoil, whereas the tico, or Costa Rican, is defined by its nation's uniqueness within Central America and therefore linked to an idyllic past, a predominantly "white" population, an affluent middle class, and a stable democracy (xiii-xvi, 62). ${ }^{15}$ With these identity stereotypes and increased migrations, Nicaraguan (im)migrants have become the scapegoat for Costa Rica's socioeconomic and political problems of the twenty-first century. ${ }^{16}$ Thus, despite Costa Rica's reputation as a friendly refuge for (im)migrants, as exemplified by the 1992 and 1994 amnesties offered to undocumented "foreigners" and the 1999 amnesty extended to Central American refugees, lawmakers responded to public anxieties about (im)migration and redefined it as a security issue in 2006 (Sandoval, Threatening 147; Sandoval, Introducción xiv-xv). The new law tightened migratory controls and gave more power to the authorities, therefore widening the gap between the two countries rather than improving hostilities.

In the liner notes that accompany Quiero que sepas, Perrozompopo addresses tensions between the neighboring countries and describes the album's collaborative project as an attempt to bridge their differences. He writes, "En este proyecto trabajamos nicaragïenses y costarricenses . . . pues solo el arte y la cultura borra fronteras, acerca a los pueblos, elimina rencores, hace comprender al otro y nos da una identidad, la identidad de la justicia y la denuncia" ("Liner"). Perrozompopo therefore responds to this urgent social issue by bringing together Nicaragua and Costa Rica through his music collaborations and volcanto lyrics, performing powerful audiotopias that imagine a more united Central America and a borderless world in which race, class, gender, and nationality do not matter. Kun suggests that music, by functioning as a possible utopia, is more than sound to our ears; it is also "a space that we can enter into, encounter, move around in, inhabit, be safe in, learn from" (2). With this understanding, audiotopias are also "contact zones" because they are musical spaces of difference where individuals from disparate places and cultures can coexist (23). ${ }^{17}$ Thus, music invites us to negotiate our own identities and those of others, trying on different versions of ourselves as we listen to varying tunes and enter into alternate cultural spaces.

Perrozompopo takes listeners to alternate cultural spaces with his third album Canciones populares contestatarias (2010)-hereafter referred to as CPC-by providing free access to it and by marketing it internationally. When CPC was launched in 2010, listeners were able to download it free of charge from the singer's website (http://www.perrozompopo.com), and even though the website is no longer active, the songs are still available on YouTube (http://www.youtube.com/watch?v=rBGvEddI7go). Three thousand copies of the $\mathrm{CD}$ were also handed out for free in Nicaragua and Costa Rica ("Perrozompopo"). The audio(u)topian goal of this accessibility was to expose young listeners to volcanto music who otherwise may not have the purchase power to engage the sounds of socially committed music ("Perrozompopo"). The title of the CD is thus a play on words that invokes a double meaning of the word populares as both beloved protest songs and protest songs of the people. Perrozompopo's commitment to volcanto music therefore continues with his third album. He recycles the themes previously discussed, such as migration, corruption, poverty, and neoliberalism, with the purpose of educating Nicaraguan youth and contributing to the country's collective memory. When discussing his third album, he commented, "Pienso que es importante que la música sirva para reforzar valores y crear conciencias, así como reforzar todo el tema de la memoria histórica" ("Perrozompopo"). He then added, "En los nuevos procesos de socialización, que van de la mano con el desarrollo de la tecnología y la globalización de todos los mercados, esta socialización . . . promueve una apertura falsa, oportunidades falsas y valores falsos" ("Perrozompopo"). Perrozompopo thus subverts this socialization process by using the Internet, a global technological highway and a virtual heterotopia, to reach young listeners with his audio(u)topian message of social justice.

Perrozompopo further undermines the global marketplace by providing free access to CPC to focus attention on the local situation in Nicaragua. While all of his lyrics can be interpreted through the local lens of his native country, the songs on CPC specifically mention Nicaragua and Managua more than the songs on his other CDs. "Pasando más" "Despierta o te mueras," "El país de la mentira," and "El mundo se cae" are examples of songs on CPC that offer direct criticisms of the social injustices, political corruption, and greed in Nicaragua. "Pasando más," in particular, describes the problems in Managua with the opening lines of each verse: "Vivo en Managua la ciudad de la venganza / . . . Vivo en Managua la ciudad que 
tanto duele / ... Vivo en Managua donde reina la carencia / . . Vivo en Managua la ciudad que no descansa." The final verse then brings the message to a climax, asking Nicaraguans to open their eyes, ears, and minds:

Vivo en Managua la ciudad adormecida, una ciudad que va perdiendo su color,

una ciudad que se ha quedado sordomuda, una ciudad que ciegamente ya no ve,

por eso digo que los nicas no debemos

quedarnos ciegos, sordos, mudos sin pensar

porque los malos desde ahora están planeando

matar con miedo la manera de pensar.

While Perrozompopo has addressed listeners in previous songs with tiu and ustedes, this is the first time he uses the word nicas, which is a common nickname for Nicaraguans. The repetition of "Vivo en Managua" also situates the singing voice in the capital city, offering the listener a firsthand account of the problems at hand. These strategies are significant as they serve Perrozompopo's audio(u)topian goal of educating Nicaraguan youth about the country's sociopolitical reality. The lyrics promote the need to be free thinkers to uncover Nicaragua's "truth," suggesting that censorship or the manipulation of information by the powers that be (los malos) is one of the country's biggest obstacles.

The topic of migration offers another case in point to the specificity on $C P C$ with the songs "Mirando al sur" and "Dejavú." Similar to "Quiero que sepas" on Perrozompopo's second album, "Mirando al sur" speaks to the geographic, linguistic, cultural, and emotional fronteras that one might encounter when traveling from north to south. The rock ballad "Dejavú" goes one step further, however, by using the familiar nicknames of tico and nica to address tensions between Nicaraguans and Costa Ricans:

No importa si el color sobre mis venas es moreno, no importa si acompaño la caída del café,

no importa si soy un mendigo, un puto callejero,

si soy nica, hondureño, si soy tico de Tibás.

No importa si en la noche cuido carros para ustedes,

no importa si en la Carpio soy un nica indocumentado

no importa si a tus hijos yo les canto las canciones

que allá detrás del río, que allá detrás del río,

que allá detrás del río he dejado de cantar. (Emphasis added)

The song lyrics and repetition of the phrase "No importa" serve to erase the socioeconomic, racial, ethnic, and national differences between nicas and ticos and between all individuals in general. La Carpio, a poor neighborhood on the outskirts of San José primarily inhabited by Nicaraguans, has been stereotyped by the media as a violent place where criminals live, and so mentioning it is another attempt to reconcile the tensions between the two groups and to empower the Nicaraguan community in Costa Rica. With both songs- "Mirando al sur" and "Dejavú"-Perrozompopo renews the audio(u)topian plea from his second album for a more united Central America without borders.

With such specific references to Nicaragua, it is not surprising that CPC is Perrozompopo's only album thus far to be recorded in Managua. With financial help from the Agencia Española de Cooperación Internacional para el Desarrollo (AECID), it was produced by the local company Momotombo Producciones in collaboration with musicians from Nicaragua, Costa Rica, and Mexico. The support from AECID also enabled it to be marketed through the Centros Culturales de España in Central America, Miami, and Mexico City, which allowed for more regional and international exposure. The collaborations that brought $C P C$ to fruition and its accessibility on the Internet have allowed Perrozompopo to further define his artistic identity as one with transnational connections and technological advantages without sacrificing his social concerns and volcanto roots. His musical style also continues to unfold as he included horns on this album, the trombone in particular, to give listeners a new sound that mixes jazz and hip-hop on songs like "El país de la mentira" and "9 días." While tensions between the local and the global have always influenced Perrozompopo's career and hybrid musical style, they are particularly present, as shown, on his third album. It is thus both fitting and ironic that he inserts himself into the international music scene with $C P C$, which earned him a Latin Grammy nomination for Best Alternative Album in 2010.

The exposure from Perrozompopo's Latin Grammy nomination opened up new musical opportunities for the singer-songwriter, allowing him to transcend the local music scene and break through the mainstream music industry. He recorded his fourth album Mundo (2014), his biggest and most expensive production to date, in Los Angeles under the label Cosmica Records (Rogers). It was released in 2014 on iTunes, and the title track "Mundo" was featured on MTV Iggy, a website focused on bringing cutting-edge global music and pop culture to the United States (Roiz). As one might infer from the album title, it is Perrozompopo's world debut as an artist, and hence the song lyrics are more universal in an attempt to appeal to a diverse listening public. The songs primarily deal with love and loss with no mention of Nicaragua or Central America. While Perrozompopo's voice remains constant and identifiable, the album sound is more synthesized and once again his hybridity emerges with new sounds. For example, with the song "El perro y la flaca," he ventures into the world of Mexican norteño music with the accordion as its signature sound. The song is a duet with lead singer Marisoul from the Mexican American band Santa Cecilia and 
a good example of Perrozompopo's attempt to appeal to new listeners with this fourth album.

Upon listening to the ten tracks on Mundo, one might wonder if Perrozompopo has abandoned his volcanto roots in exchange for exposure and fame; however, the first song on the album, "Quiero decirles," seems to be a (re)new(ed) artistic manifesto that expresses audio(u)topian concerns. The song opens with the chant, "El pueblo unido jamás sera vencido," which any Spanish-speaking listener will identify as a call for social action and a 'utopian plea for equality. More specifically, this phrase references a famous song from Chile's Nueva Canción movement that was recorded in 1973 to reflect Salvador Allende's socialist platform and the spirit of working-class individuals. It was then made famous around the world after Allende died in the military coup that brought Augusto Pinochet to power. Perrozompopo's use of this phrase as an intertext sends a strong message to listeners about his leftist ideology and solidarity with $e l$ pueblo. Thus, is it fitting that he begins the album with this reference to (re)introduce himself to the world as an artist with social concerns. After a group of voices chants this famous phrase, the opening line of the song states, "Quiero decirles que a partir de ahora yo ya no tengo más fronteras / . . Soy un artista que trabaja día a día como un perro." Perrozompopo then goes on to explain further what kind of an artist he is:

Yo no soy un tipo irreverente,

a mí me gusta sentarme a la mesa,

me gusta también decirte las cosas directas

como un preacher lanza su recta.

With this, Perrozompopo takes to heart his plea for a world without borders and presents himself as an artist without geographical, personal, or professional boundaries. Rather than describe himself as an artist from Nicaragua or connect to his family's music legacy, as on his first CD, he is now an artist of the world. And while he has always been global, it seems that there is a conscious effort with his fourth album to cast a wider net through his artistic endeavors.

In conclusion, one clearly sees growth and change in analyzing the arc of Perrozompopo's musical career, but one constant remains: his commitment to the volcanto tradition. As shown, his first album Romper el silencio grounded his music in this tradition with protest songs about politics and socioeconomic concerns in Nicaragua, whereas his second album, Quiero que sepas, built a cultural bridge between Costa Rica and Nicaragua. The goal of his third album $C P C$ was to empower Nicaraguan youth through accessibility, and his fourth album Mundo launched him onto the international stage. While Perrozompopo may have softened his overt criticisms on this latest $\mathrm{CD}$, the exposure to a more diverse listening public gives him a wider platform from which to express his social concerns. I argue, therefore, that even though his career has moved from the national and regional stage to the global one, Perrozompopo has stayed connected to his volcanto roots, and his music continues to open up sonic spaces of utopian desires. His music reimagines the volcanto tradition and expands its reach as a transnational one with global concerns, hybrid sounds, and new platforms. One such platform is social media, as Perrozompopo has an active Facebook page in which he communicates with fans, announces concerts, and writes poetic messages. A post from April 30, 2015, for example, indicated that he was working on a new album and a book of poems. ${ }^{18}$ Perrozompopo also recorded a TED Talk titled "Migración, amor y poder de cambio" in Costa Rica in January 2015. In the talk, he describes the experiences, including being a migrant in Costa Rica, that have both humbled and inspired him to grow, and he also performs several songs, including "Quiero que sepas," about crossing borders from north to south. The talk is available on YouTube (http://www.youtube.com/watch?v=ZgBiENaxF8A), thus affording him another platform from which to communicate his message of building bridges. While the full impact of his global launch has yet to be measured, his continued transformation, true to his artistic name of Perrozompopo, remains to be seen.

\section{Notes}

1. The Mejía Godoy family is very well known in Nicaragua for its musical talent. Luis Enrique Mejía Godoy, Carlos's brother, is also connected to the volcanto tradition. Ramón Mejía's brother, the other Luis Enrique, is a Grammy-winning salsa singer, and his cousins, Augusto Mejía and Carlos Emilio Guillen Mejía, participate in Nicaragua's most popular younger bands, including Momotombo and La Cuneta Son Machin (Rogers). The family has a restaurant in Managua called La Casa de Los Mejía Godoy where fans can purchase their albums in the gift store and listen to popular music on the live stage. Therefore, the family continues to foster musical talent and traditions in Nicaragua.

2. Roland Robertson proposed the concept of glocalization in the mid-1990s to explain the relationship between the global and local and to account for heterogeneity in the process of globalization. Robertson dispels the notion that the global and local are mutually exclusive, arguing that any idea or product coming from the outside must be adapted to a particular local context, whether it be regional, ethnic, or national (546).

3. Much like the Mejía Godoy family in Nicaragua, Violeta Parra's children, Isabel and Ángel, are also Chilean folksingers. Both of these families give testament to a generational tradition of artists committed to improving social and political inequalities in Latin America.

4. Contemporary Chilean singers, like Manuel García and Camila Moreno, are continuing the tradition of Nueva Canción in the Southern Cone. García, for example, recorded the song "Santiago de Chile" as a tribute to Silvio Rodríguez, and his 
second album Témpera (2008) includes references to Violeta Parra and Atahualpa Yupanqui. Furthermore, alt.latino's Jasmine Garsd has compared Moreno to Mercedes Sosa and Violeta Parra ("Spotlight"). Moreno's most famous song "Millones" from her 2009 album Almismotiempo is a protest song about the greed of transnational pharmaceutical companies and was nominated for a Latin Grammy in the Best Alternative Song category.

5. The son nica was "invented" in the 1940s by Camilo Zapata, who turned to the marimba de arco trios from the Masaya region near Managua for stylistic inspiration. The trio consists of a marimba with a guitar and a smaller four-stringed guitarrilla. This combination of instruments produces a sound that is almost entirely in major keys, which is the distinctive marker of the Nicaraguan son nica (Scruggs, "Socially Conscious" 45-46).

6. The group Duo Guardabarranco, comprising brother and sister Salvador and Katia Cardenal, exemplifies how artists were able to reinvent themselves after the Sandinistas lost power. For example, they were drawn to pop music and rock ballads more than Nicaraguan sounds like the son nica; however, their songs still imagined a more just world, promoting the universal themes of freedom, peace, and ecology (Sturman 258-62). In "Nostalgia for the Future," Janet L. Sturman writes, "While the music of Carlos Mejía Godoy embodies his messages, for the Duo Guardabarranco, the music is the servant, an attractive bearer, for their powerful lyrics" (260).

7. I was fortunate to attend one of these peñas during my visit to Managua in May 2008. Katia Cardenal, who by then had become a solo artist, was the headline singer for the evening, and it was clear from the audience's reaction that she has a special connection to the Nicaraguan public.

8. The reelection of Daniel Ortega in Nicaragua follows a general trend of a return to leftist politics in Latin America at the beginning of the twenty-first century. Other examples of socialist leaders include Evo Morales in Bolivia, Hugo Chávez in Venezuela, Rafael Correa in Ecuador, and Néstor Kirchner and Cristina Fernández de Kirchner in Argentina.

9. Carlos Mejía Godoy was the 2006 vice-presidential candidate for the Movimiento Renovación Sandinista (MRS), which was founded by dissidents of the FSLN. The beloved singer stepped in at the last minute when the original vicepresidential candidate Edmundo Jarquín replaced presidential candidate Herty Lewites after he suffered a fatal heart attack four months before the election.

10. According to their website, "Papaya Music is a consortium of musicians, producers and researchers who want to rescue traditional popular composers from oblivion, encourage young people to go back to their roots, inspire new musical forms and ensure that the artists receive fairer remuneration for their work" (http:// www.papayamusic.com). With its headquarters in Costa Rica, the label is available throughout Central America. When I traveled to the region in May 2008, a collection of Papaya CDs, including Perrozompopo's Quiero que sepas, was marketed and sold in airport shops and available at cafés, bookstores, and department stores in the capital cities.

11. According to their website (http://www.vocesnuestras.org), Voces Nuestras is based in San José but works throughout Latin America to promote communication among social sectors, such as indigenous groups, environmental groups, and women's organizations, that traditionally have been excluded from developmental and democratic processes in the region.

12. Two of the musicians-Iván Rodríguez and Carlos "Tapado" Vargas-who collaborated with Perrozompopo on "Ríos de gente" and his entire second album are members of the popular Costa Rican rock group Malpaís. On their 2006 live album, Malpaís also recorded a song about migration titled "Contramarea" that tells the story of a pair of star-crossed lovers, a Costa Rican girl and a Nicaraguan border patrol agent, who are divided by the San Juan River and social tensions between the two countries. While an analysis of "Contramarea" is beyond the scope of this article, it did win Song of the Year at Costa Rica's 2008 music awards (ACAM).

13. Perrozompopo was born in 1971 when the anti-Somoza struggle was gaining force.

14. According to the 2000 census, Nicaraguans accounted for 76.4 percent of the three hundred thousand foreign-born residents in the country, and of this total 50 percent were women (Castro Valverde 26,32 ). More recent statistics show that in 2011 Nicaraguans constituted 6.6 percent of the total population in Costa Rica, up slightly from 5.9 percent in 2000 (Sandoval, "To Whom" 1431). While the numbers between 2000 and 2011 remained somewhat steady, the negative perception of the Nicaraguan "other" has intensified over time.

15. Costa Rica's "uniqueness" or "exceptionalism" has been credited to the dissolution of its army in 1949, leading to a stable and peaceful democracy, unlike its Central American neighbors with long histories of civil wars and military rule. The country is also known as the "Switzerland of Central America" because of its relatively high standard of living and implementation of social welfare programs that have provided citizens with access to education and health care. Furthermore, Costa Rica has taken great pride in protecting its natural resources, becoming a leader in environmental conservation and ecotourism.

16. The adoption of neoliberal economic policies in Costa Rica has contributed to a decrease in social services, compromising the government's investment in its people, which in turn has led to criticisms of the political system (Booth, Wade, and Walker 62-64).

17. In her study Imperial Eyes on travel writing and transculturation, Mary Louise Pratt originally defined the phrase "contact zones" as "social spaces where disparate cultures meet, clash, and grapple with each other, often in highly asymmetrical relations of domination and subordination" (4).

18. His new album, Dos Tiempos, will be released in November 2017.

\section{Works Cited}

Alvarenga Venutolo, Patricia. "Los migrantes nicaragüenses en Costa Rica." ISTMO, vol. 4, 2002, http://collaborations.denison.edu.istmo/.

Arriaza, Alejandro. "Un vistazo a la trova y su historia." Siglo Veintiuno, 17 Feb. 2008.

Booth, John A., Christine J. Wade, and Thomas W. Walker. Understanding Central America: Global Forces, Rebellion, and Change, 4th ed., Westview, 2006. 
Castro Valverde, Carlos. "Dimensión cuantitativa de la inmigración nicaragüense en Costa Rica: Del mito a la realidad." El mito roto: Inmigración y emigración en Costa Rica, edited by Carlos Sandoval García, Editorial UCR, San José, 2007, 25-50.

Fouratt, Caitlin E. "Those who come to do harm': The Framings of Immigration Problems in Costa Rican Immigration Law." International Migration Review, vol. 48 , no. 1, 2014, 144-80.

García, Manuel. "Santiago de Cuba." YouTube, 28 Feb. 201l, https://www youtube.com/watch?v=iqaMc9eqMQw.

- Témpera. Alerce Producciones, 2008.

Garsd, Jasmine. "Spotlight On: Camila Moreno's 'Lo cierto." alt.latino, 1 Feb. 2011.

Kun, Josh. Audiotopia: Music, Race, and America. U of California P, 2005.

Lopez, Ann. "Breaking the Silence." The World, 3 Nov. 2006.

Malpaís. "Contramarea." Malpais en vivo. Papaya Music, 2006

Mejía Godoy, Luis Enrique. "Romper el silencio." Lo mejor de los Mejía Godoy. NICARIB Productions, 2007.

Moreno, Camila. "Millones." Almismotiempo. Sello Azul, 2009.

Muñoz, Néfer. "Perrozompopo, un músico sandinista y un rebelde con causa." $B B C$ Mundo, 8 May 2013.

Pérez, Julián. "La Radionovela, de moda en Centroamérica." Terra Colombia, 7 Nov. 2008.

Perrozompopo. Canciones populares contestatarias. Producciones Momotombo, 2010.

. Liner notes. Quiero que sepas. Papaya Music, 2007.

"Manifiesto." Romper el silencio. Delicias Discográficas, 2004

"Migración, amor y poder de cambio." TEDx: PuraVidaJoven, San José,

Costa Rica, 16 Jan. 2015, http://www.youtube.com/watch?v=ZgBiENaxF8A/

. Mundo. Cosmica Records, 2014

Quiero que sepas. Papaya Music, 2007.

Romper el silencio. Delicias Discográficas, 2004.

"Perrozompopo lanza su tercer disco: CPC (Canciones Populares Contestatarias)." Cancioneros.com, 4 Feb. 2010.

Pratt, Mary Louise. Imperial Eyes: Travel Writing and Transculturation. Routledge, 1992.

Rios de gente, directed by Marvin Murillo, performed by Perrozompopo. Papaya Music de Centroamérica, 2007, http://www.youtube.com/watch?v=C7_00Sa9Mcw.

Robertson, Roland. "Glocalization." Encyclopedia of Globalization, edited by Jan Aart Scholte and Roland Robertson, Routledge, 2007, vol. 2, 545-48.

Rogers, Tim. "Perrozompopo Eyes International Stage." Nicaragua Dispatch, 22 Oct. 2012.

Roiz, Jessica Lucia. "Perrozompopo Empowers Nicaragua through His Music." VOXXI, 24 July 2014.

Sandoval García, Carlos. Introducción. El mito roto: Inmigración y emigración en Costa Rica, edited by Sandoval, Editorial UCR, San José, 2007, xiii-xxiii.

- Threatening Others: Nicaraguans and the Formation of National Identities in Costa Rica. Ohio UP, 2004.
"To Whom and to What Is Research on Migration a Contribution." Ethnic and Racial Studies, vol. 36, no. 9, 2013, 1429-45.

Scruggs, T. M. "Central America: Nicaragua." Continuum Encyclopedia of Popular Music of the World, 5th ed., Bloomsbury, 2005, vol. 3, 172-78.

- "Music, Memory, and the Politics of Erasure in Nicaragua." Memory and the Impact of Political Transformation in Public Space, edited by Daniel J. Walkowitz and Lisa Maya Knauer, Duke UP, 2004, 255-75.

. "Socially Conscious Music Forming the Social Conscience: Nicaraguan Mísica Testimonial and the Creation of a Revolutionary Moment." From Tejano to Tango: Latin American Popular Music, edited by Walter Aaron Clark, Routledge, 2002, 41-69.

Sturman, Janet L. "Nostalgia for the Future: The New Song Movement in Nicaragua." Latin American Popular Culture Since Independence, edited by William H. Beezley and Linda A. Curcio-Nagy, 2nd ed, Rowman \& Littlefield, 2012, 247-66. 